\title{
The Use of Modal Must and Have to in the Corpus of Contemporary American English
}

\author{
Komang Adi Maendra ${ }^{1}$, I Nengah Sudipa ${ }^{2}$, Putu Weddha Savitri ${ }^{3}$ \\ English Department - Faculty of Arts - Udayana University \\ ${ }^{1}$ [adi.maendra@gmail.com] ${ }^{2}$ [nengahsudipa@yahoo.co.id] \\ 3 [weddha_savitri@unud.ac.id] \\ *Corresponding Author
}

\begin{abstract}
The title of this study is The Use of Modal "Must" and "Have to" in the Corpus of Contemporary American English. It aimed at finding structures and identifying meanings of the modals in the Corpus of Contemporary American English (COCA). COCA was used as the data source on http://corpus.byu.edu/coca/. Documentation method was applied in collecting the data in this study. The data were identified, classified, and analyzed about structures and meanings of modal "must" and "have to" by the main theory of Quirk. The results show that the structure of modal "must" followed by verb classes is the most frequently used, second is verb phrases, third is adverbs, and fourth is indefinite pronouns and quantifier positions. The structure of modal "have to" that is followed by verb classes is also the most frequently used, furthermore is verb phrases. Meanwhile, the meaning of modal "must" expresses more messages than the meaning of modal "have to". Modal "must" expresses a condition cannot be changed or unavoidable obligation, the obligation or necessity from inside the speaker, the idea of necessity, the logically necessary, and the wishes or intentions of the person one is speaking to. Modal "have to" expresses the obligation from outside the speaker, the idea of obligation or repetition, and the unavoidable obligation.
\end{abstract}

Keywords: modality, corpus, and structures

\begin{abstract}
Abstrak
Judul studi ini adalah The Use of Modal "Must" and "Have to" in the Corpus of Contemporary American English. Studi ini bertujuan untuk menemukan struktur dan menganalisa arti dari kedua modal tersebut dalam Corpus of Contemporary American English (COCA). COCA dipakai sebagai sumber data yang dapat diakses melalui website http://corpus.byu.edu/cocal. Metode dokumentasi digunakan dalam pengumpulan data pada studi ini. Data yang telah didapat kemudian diidentifikasi, diklasifikasi, dan dianalisa untuk mencari struktur dan arti dari modal "must" dan "have to" menggunakan teori utama dari Quirk. Hasil dari studi ini menunjukan bahwa struktur dari modal "must" yang diikuti oleh kelas kata kerja merupakan yang paling sering digunakan, kedua adalah frasa kata kerja, ketiga adalah kelas kata keterangan, dan keempat adalah kelas kata ganti yang tidak tentu dan kelas kata posisi pembilang. Struktur dari modal "have to" yang diikuti oleh kelas kata kerja juga merupakan yang paling sering digunakan, setelahnya adalah frasa kata kerja. Sementara itu, arti dari modal "must" mengekspresikan lebih banyak pesan daripada arti dari modal "have
\end{abstract}


to". Modal "must" mengekspresikan sebuah keadaan yang tidak bisa diubah atau dihindarkan, keharusan dari dalam pembicara, ide tentang keperluan, logika yang diperlukan, dan harapan atau maksud seseorang terhadap orang lain yang diajak bicara. Modal "have to" mengekspresikan keharusan dari luar pembicara, ide tentang keperluan atau pengulangan, dan kewajiban yang tidak bisa dihindarkan.

Kata kunci: modality, corpus, dan struktur

\section{Background of the study}

An auxiliary verb is a verb that helps another verb for making a complete structural sentence. The modal verb cannot stand alone without another verb or we know as a full verb in a sentence. (Hornby, 1987: 558)

Modal "must" and "have to" have the same grammatical meaning where "must" comes from the internal speakers' point of view and "have to" comes from the external speaker' point of view. (Kreidler, 1998: 241).

The reason for choosing corpus texts as the object of analysis is because they usually consist of thousands or millions of words and they are not made up of the linguist's or native speaker's invented examples but on authentic or naturally occurring spoken and written language. (Davies, 1990).

\section{Problems of the study}

Based on the background, the problems of this study can be formulated as follows:

1. What are the structures of modal "must" and "have to" in the Corpus of Contemporary American English?

2. What are the meanings of modal "must" and "have to" in the Corpus of Contemporary American English?

\section{Aims of the study}

Based on the formulation of the above problems, this study is investigated in order to find the following purpose:

1. To find out the structures of modal "must" and "have to" in the Corpus of Contemporary American English.

2. To identify the meanings of modal "must" and "have to" in the Corpus of Contemporary American English.

\section{Research Method}

Research method describes how the research is done. It can be defined as the procedures on the method used in writing a scientific paper which in this case includes the data source, method and technique of collecting data, method and technique of analyzing data, and method and technique of presenting analysis.

\subsection{Data Source}

The data were taken from the Corpus of Contemporary American English on http://corpus.byu.edu/coca/. It was chosen as a data source because it is the largest freely-available corpus of English and the only large and balanced corpus of American English. It is probably the most widely-used corpus of English which contains more than 520 millions word texts (20 million words each year 19902015). The data on the corpus is divided among spoken, fiction, magazine, newspaper, and academic texts. 


\subsection{Method and Technique of Collecting Data}

Documentation method was applied in conducting the data in this study. The data were taken from the Corpus of Contemporary American English on http://corpus.byu.edu/coca/. First, an account must be created to signing to the website. Second, click "SEARCH" menu and type the modal "must" and "have to" one by one in POST LIST with these patterns; In the [nn*], On the [nn*], and At the [nn*]. Third, click "SECTION" and choose "fiction". Fourth, click the "OPTION" and choose 50 data for each modal on \#HITS and \#KWIC of corpus texts that would be displayed; the data of modal "must" and "have to" would be limited to 100. Fifth, press "ENTER" on the keyboard to show the data. Sixth, the data were input into Microsoft Word of a computer program. Finally, the collecting data were classified and analyzed to find their structures and meanings.

\subsection{Method and Technique of Analyzing Data}

First, the data were identified. Second, the data were classified into some groups and each of them was classified based on word classes followed. Third, the data were analyzed descriptively and quantitatively based on the main theory of Quirk (1985) and the supporting theory of Kreidler (1998).

\subsection{Method and Technique of Presenting Analysis}

The data in this study are presented descriptively. They are presented by giving some descriptions to convey the structures and meanings of modal "must" and "have to" in the sentences.

\section{Analysis}

This chapter answers the problems formulated in the previous chapter to find out the structures and to identify the meanings of modal "must" and "have to" with reference to The Corpus of Contemporary American English.

\subsection{Structures and Meanings of Modal "Must"}

This part discusses the structures of modal "must" by checking what word classes follow after the modal "must".

\subsubsection{Structure of Modal "Must" Is Followed by Verb Phrases}

Data 1

So each ship must end up with at least one person aboard.

The modal "must" in the above sentence is followed by the phrase "end up", it consists of verb end + adverb up. It expresses a condition which cannot be changed. There must be one person at least to control the ship.

Data 2

So that as he hangs there he must force down thin wedges of breath into painful congestion.

The modal "must" in the above sentence is followed by the phrase "force down", it consists of verb force + adverb down. It expresses the obligation from inside the speaker. He makes an activity where he hangs on somewhere, it makes him must force down his power and controls the breath.

\subsubsection{Structure of Modal "Must" Is Followed by Verb Classes \\ Data 12 I've never considered myself a petty sort, but I must admit it gave me a great deal of satisfaction.}


The modal "must" in the above sentence is followed by the full verb "admit". It expresses a condition which cannot be changed. The speaker (I) is the petty person, so he gives the obligation from inside of himself to admit this situation because it gives the speaker deal of satisfaction.

Data 13

Hell for old men arrives at that exact moment when we must admit we can no longer protect our kids and our families.

The modal "must" in the above sentence is followed by the full verb "admit". It expresses unavoidable obligation or a condition which cannot be changed. Where everyone was born into the world exactly will die one day. So they must admit that they cannot always protect their kids and families forever.

\subsubsection{Structure of Modal "Must" Is Followed by Adverbs}

Data 46

The nearby gang of two-legged Christmas tree ornaments must also be children in disguise, for they were spooking the horses.

The modal "must" in the above sentence is followed by the simple adverb "also". It expresses the logically necessary. It can be used to say that we are sure about something. For spooking the horses, the children must also disguise themselves into the gang of twolegged Christmas tree ornaments.

\section{Data 47}

Way of defining taste. If so, then that taste must also function with new plays.

The modal "must" in the above sentence is followed by the simple adverb "also". It expresses the obligation from inside the process. The above sentence discusses the way of defining taste, so there is a command to require that way of taste must also function with new plays.

\subsubsection{Structure of Modal "Must" Is Followed by Indefinite Pronouns}

Data 49

Must everybody get on my case?

The modal "must" in the above sentence is followed by the indefinite pronoun "everybody". It expresses the wishes or intentions of the person one is speaking to. The speaker (I) is speaking to everybody, he asks about his case. Must he give his case to everybody?

\subsubsection{Structure of Modal "Must" Is Followed by Quantifier Positions}

Data 50

He groaned as he thought that it must all be gone through again.

The modal "must" in the above sentence is followed by the quantifier position "all". It expresses the idea of necessity in reported speech. He places himself in the complicated situation of life and he imagines all that he is owned must be gone through again.

\subsection{Structures and Meanings of Modal "Have to"}

This part discusses the structures of modal "have to" by checking what word classes follow after the modal "have to".

\subsubsection{Structure of Modal "Have to" Is Followed by Verb Phrases}

Data 51

Odo would have to climb down into the cesspool and carry Wulfrith out. 
The modal "have to" in the above sentence is followed by the phrase "climb down", it consists of verb climb + adverb down. It expresses the obligation from outside the speaker. Odo has to climb down into the cesspool to save Wulfrith because Wulfrith needs Odo's help to go out from the cesspool.

Data 52

She and Tom would have to figure out more child care for the boys.

The modal "have to" in the above sentence is followed by the phrase "figure out", it consists of verb figure + adverb out. It expresses the idea of obligation. Child care is one of the best ways to keep the child from something is not wanted such as disease. So, she and Tom have to figure out about the child care especially for the boys.

\subsubsection{Structure of Modal "Have to" Is Followed by Verb Classes}

Data 57

Want to go to heaven when he did, but you have to accept he's gone, son.

The modal "have to" in the above sentence is followed by the full verb "accept". It expresses the idea of obligation. The son has to accept the reality that someone he loves so much has gone forever and he would not be back again.

Data 58

The natives will have to accept it. Better we offend them than the Thtresh.

The modal "have to" in the above sentence is followed by the full verb "accept". It expresses the idea of obligation. There are two choices which we can do. We offend the natives or the
Thtresh. We have to do it to the natives because they will accept it.

\section{Conclusions}

The structures of modal "must" in the sentences which were found in the Corpus of Contemporary American English can be classified into five groups. They are modal "must" is followed by verb phrases, verb classes, adverbs, indefinite pronouns, and quantifier positions. The most frequently used after the modal "must" is the verb classes. On the other hand, the structures of modal "have to" can be classified into two groups. They are modal "have to" is followed by verb phrases and verb classes. The most frequently used after the modal "have to" is the verb classes.

The meanings of modal "must" in the sentences found in the Corpus of Contemporary American English express some messages. They are expression of a condition which cannot be changed or unavoidable obligation, expression of the obligation or necessity from inside the speaker, expression of the idea of necessity, expression of the logically necessary, and expression of the wishes or intentions of the person one is speaking to. On the other hand, the meanings of modal "have to" express some messages such as expression of the obligation from outside the speaker, expression of the idea of obligation or repetition, and expression of the unavoidable obligation.

\section{Bibliography}

Brown, H. Douglas. (1987). Principles of Language Learning and Teaching. Prentice-Hall Inc, New Jersey. 
Davies, M. (1990). Corpus of Contemporary American English (COCA) [Internet]. Available from: http://corpus.byu.edu/coca/ [Accessed 28 July 2017].

Kreidler, Charles W.(1998). Introducing English Semantics. Routledge, London.

Quirk, Randolph et al. (1985). A Comprehensive Grammar of the English Language. Longman Ltd, London. 